\title{
COLLAPSE DOLINES AND DEFLECTOR FAULTS AS INDICATORS OF KARST FLOW CORRIDORS
}

\author{
France ŠUŠTERŠIČ
}

\begin{abstract}
The paper concerns collapse dolines, which appear to be one of the best-defined surface karst phenomena. Despite this appearance, one may find quite different views in the literature, and some of the aspects of their morphogenesis have been overlooked completely. Among these aspects the most obvious is the question of the ongoing development of the closed depression. Five of the most common collapse doline types found in Slovenia are considered in terms of general systems theory, leading to a conclusion that cave roof collapse remains the crucial event in a collapse doline's development. However, the collapse event itself may be relatively subdued in terms of the volume of free fallen mass involved. Some types of collapse dolines appear along particular types of faults that function as a kind of screen; these faults are termed deflector faults. They are marked by collapsing within the caves, and by "active" collapse dolines on the surface. Existence of deflector faults is an indicator of flow corridors in the close neighbourhood.
\end{abstract}

KEYWORDS: collapse dolines, cave breakdown

\section{Introduction}

Larger scale karst subsidence phenomena that characteristically involve an element of catastrophic development are discussed. These were long ago added to the standard inventory of geomorphologicl features, and are referred to generically as collapse dolines. The central ideas of karst science have remained essentially unchanged for more than a century (see Cramer, 1944, p.327), but field study has revealed a variety of evidence that makes the general understanding of the expression "collapse doline" much wider (Šušteršič, 2000a). This paper:

- describes and interprets the situations most commonly found in the Slovenian Classical Karst;

- demonstrates that the role of some types of feature changes over time;

- discusses practical uses of these findings in understanding the hydrogeology of the karst.

Aspects discussed in the paper are applicable to many karst areas, but most are based on field examples within the Classical Karst of Slovenia. More regional details are provided by Šušteršič $(1996,2000 b)$. 


\section{Geomorphic processes}

In this paper, collapse dolines are considered strictly as projections of underground negative masses at the surface. However, whether all collapse phenomena at the surface originated in this way, is arguable.

General understanding of basic karst processes is that development of collapse dolines is controlled by two sets of factors:

\begin{tabular}{|r|c|l|}
\hline Underground mass removal & $\rightarrow$ & generation of doline volume \\
\hline (trans)formation of doline slopes & $\rightarrow$ & generation of doline shape \\
\hline
\end{tabular}

Intuitively, the basic geomorphic processes (generally, but not inevitably, starting at the top of the Table 1) involved appear to be:

Table 1. Geomorphic processes involved in collapse doline development

\begin{tabular}{|c|l|l|l|}
\hline $\mathbf{1}$ & $\mathbf{R M}$ & Underground removal of fallen material & \multirow{2}{*}{ VOID (NEGATIVE MASS) } \\
\hline $\mathbf{2}$ & $\mathbf{F C}$ & Formation of large caverns & FORMATION \\
\hline $\mathbf{3}$ & $\mathbf{A P}$ & $\begin{array}{l}\text { Approach of the cavern to the surface / surface to } \\
\text { the cavern }\end{array}$ & \\
\hline $\mathbf{4}$ & $\mathbf{C L}$ & Collapse / opening of the cavern to the surface & DOLINE CREATION \\
\hline $\mathbf{5}$ & SR & Slope retreat & SHAPE \\
\hline & DD & Gradual disintegration due to denudation & (TRANS)FORMATION \\
\hline
\end{tabular}

Detailed discussion of the processes can be found within the general literature (see citations in Šušteršič, 2000a) and more detail of the scheme presented above is provided by Šušteršič (o.c.).

At first glance there appears to be a corollary that the original cave chamber must inevitably be very large at the time of doline formation. However, many field measurements (Š́ušteršič, 1973, 1974, 1997) reveal that very large collapse dolines may evolve from cave chambers of relatively modest ground plan. This can be a consequence of:

- the existence of vertically oriented negative masses (voids) within the parent rock, or/and

- prolonged mass removal, extending well into the phase of doline shape transformation.

The first possibility is the case at Vranja jama, north of Planinsko polje in southcentral Slovenia (Šušteršič, 1994), where collapse is related directly to a phreatic jump between two inception horizons (sensu Lowe and Gunn, 1997). Similar conditions are at least strongly suggested at several points within the Najdena jama system nearby, and it seems that such relationships may develop where relatively small cave channels are cut by sudden breakdown.

The second possibility is obvious in cases where extremely large dolines lie at the intersection of regional underground water flow and (in the studied cases) local strike-slip faults (Sušteršič, 1997; Šušteršič et al., 2001). In both possible situations 
tectonic loosening of the parent rock has enhanced, if not dominated, the collapse process.

Mass removal by system drains is inevitable, but it is not the only influence upon doline volume and shape. In some cases, like Dolec (collapse doline) in the Najdena jama system (north of Planinsko Polje), a permanent draught of cold air into the cave from between collapsed boulders suggests that the potential role of condensation water in corroding fallen material cannot be ignored (Šušteršič, 2000a, p.218).

Though generally not mentioned explicitly, the final step in the logical chain is the gradual disintegration of the doline's slopes and, consequently, the gradual loss of the doline's identity within the surface. Surface denudation around and within the doline is constantly active but, being relatively slow, its effects can be neglected during the time that mass removal by an underground drain and/or condensation water and parallel slope retreat are active. Later, surface denudation becomes the only agent to operate upon the doline, slowly equalising vertical differences, perhaps making the doline shallower and wider (Habič, 1978). Eventually the now-subdued former collapse doline becomes just one among a variety of hollows on the land surface. Only outcrops of cave sediments (related to intersected caverns) within the slopes testify to the origin of the hollow. Such depressions are termed phantom collapse dolines (Šušteršič, o.c., p.218).

\section{Common outcomes}

A widely but tacitly accepted idea that, within a doline, the processes listed in Table 1 operate sequentially appears obvious (i.e. only one process can operate at a time). However, field evidence does not support this oversimplification. Instead, a number of combinations may occur, resulting in a variety of outcomes that may seem contradictory. Considering negative mass transport of breakdown material as the main process (i.e. non-denudational removal by the underground drain), collapse dolines may be either closed or open systems. Even so, it must be stressed that all collapse doline development sequences have a common end point (phantom dolines).

The following figures and text do not set out to examine development sequences in detail, but describe only the more interesting aspects.

\section{Case C1: totally closed system, stable cave roof (Fig.1, C1)}

The expression totally closed system indicates that mass removal by the underground drain ceases long before the big chamber establishes a stable roof. In such cases gradual ceiling breakdown and consequent accumulation of debris on the floor will initially insulate the void from the influence of any neighbouring cave channels. The process should stop as soon as a stable arch develops (Scheidegger, 1961).

Some (perhaps exceptional) field examples demonstrate that such stability is not achieved immediately. As the process advances, the ceiling adjusts to the geostatic stress field, gradually attaining mechanical equilibrium. A parabolic arch develops (Renault, 1967) and the chamber tends towards attaining a circular, or at least elliptical, ground plan (Šušteršič, 1974). 


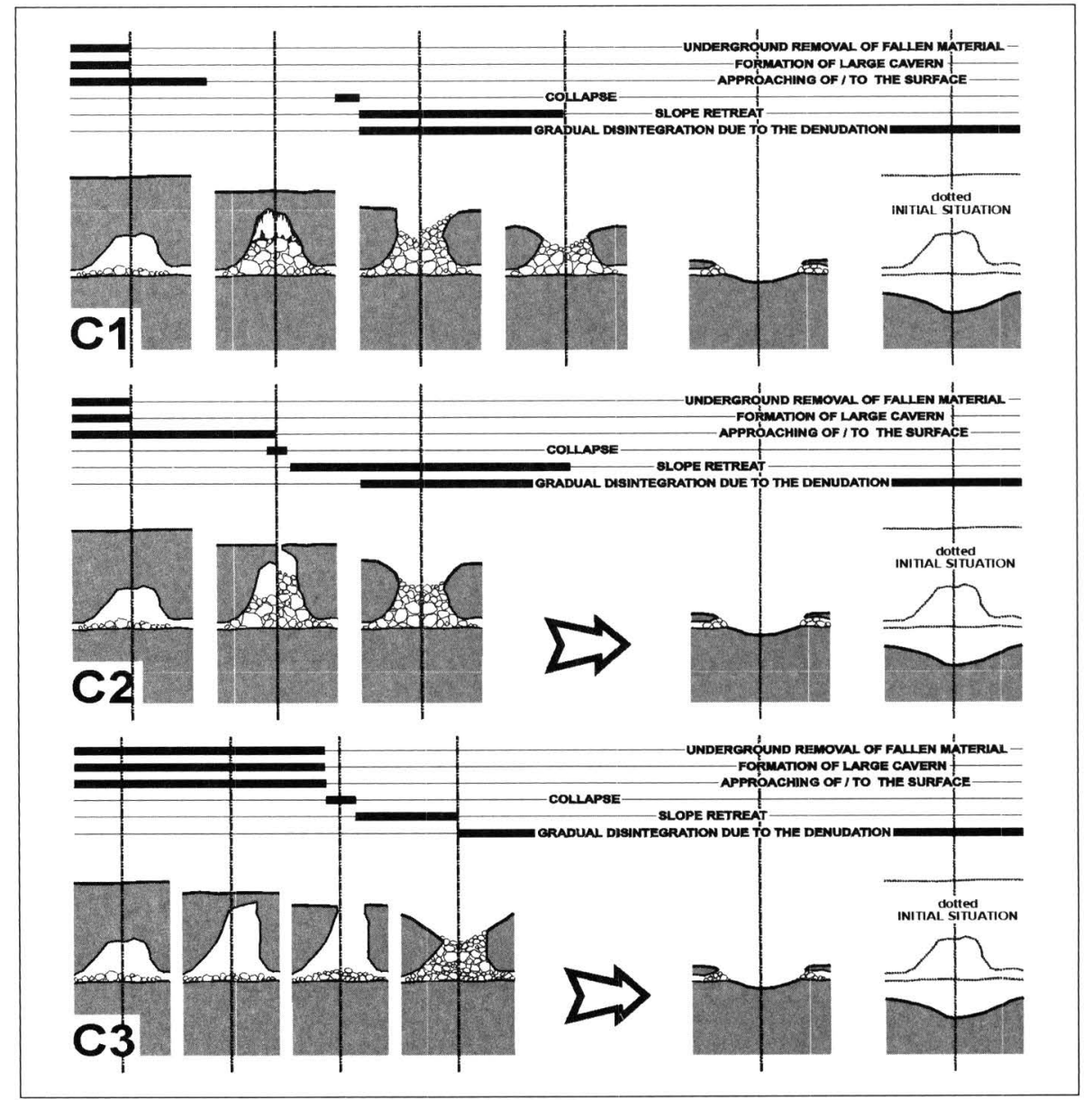

Fig.1 - Collapse doline development explained in terms of closed system conditions

Case C2: totally closed system, unstable cave roof (Fig.1, C2).

In some cases the cave roof cannot achieve a stable arch morphology. Though the cavern's ground plan may be at least equi-dimensional and tending towards elliptical or circular, the roof is highly irregular and free of flowstone cover, and collapsed debris on the floor looks fresh. The chamber is still developing, in the sense that collapse is ongoing. Such unstable cavern roofs will probably continue to decay until collapse eventually transforms the cave into a doline. Because the bulk volume of broken rock is greater than that of the solid source rock (Šušteršič, 1973), this process causes a reduction of the cave volume. However, if the rock above the original cavity is thick enough the chamber could eventually be filled completely (the void is consumed) due to the relative volume increase of the debris (Šušteršič, 1974). In such cases the breakdown process will stop before the collapse reaches the surface, and no doline will appear (Šušteršič, o.c., p.30, Fig.1b). 
Cases $\mathrm{C} 1$ and $\mathrm{C} 2$ differ in the way that the arched cave roof arrives close to the land surface - that is, how the ceiling becomes too thin to support itself. In the second case cave roof block spalling and denudational surface lowering both operate. In the first case only the latter operates and the process might be much slower overall. Though no direct measurements of the rate of roof spalling in caves of this type exist, the process appears to act much more quickly than does simple denudation.

Variations on cases C1 and C2 may develop from initial phreatic jump situations (Šušteršič, 1996). Here the original cave chamber will be little wider than neighbouring "horizontal" passages. Volume will be distributed vertically, and the roof would not be expected to be unstable. After sufficient denudational surface lowering a relatively narrow but deep, vertical-walled, depression will appear, soon to transform into a more typical collapse doline of smaller dimensions. The entrance "shaft" of Gradišnica cave (Marussig \& Velkovrh, 1959; Nagode, 1997) appears to be of this type.

Case C3: Hypothetical outcome: partly open system, closure at the time of collapse (Fig.1, C3).

This case is included because it appears to be accepted tacitly in some older literature. In 1963 Habič provided apparent support based on field observation of various collapse dolines in the area behind the Ljubljanica springs near Vrhnika. He noticed that their absolute floor levels fall within relatively few groupings, even though their rims are at various elevations. He concluded that this is the consequence of two facts:

- the caves beneath were formed at clearly defined levels, and

- removal of fallen mass lasted until the roof eventually collapsed.

For many years the validity of the former idea was, at best, uncertain, because only fragments of phreatic systems were known in the general area. Several caves have now been explored fully and the idea can be refuted. Reliable field evidence (Brenčič, 1992; Šušteršič, 1994) confirms that caves at discrete levels neither exist nor existed in this area, and there is no need to postulate them.

Case O1: totally open system, shallow underground stream (Fig.2, O1).

At some locations, where cave systems develop at relatively shallow depth, chamber ceilings will spall down progressively, until breaking through to the surface. Simultaneously, underground stream flow below is strong enough to remove collapse debris. Consequently, slope retreat within the newly formed dolines is unconstrained and they merge together. Eventually, a string of collapses will change into a canyon that will gradually be transformed into a karst valley. Denudation, however, cannot lower the floor of the depression below base level. Consequently, the valley will evolve into a wide depression with gentle slopes, which could be compared to a small karst polje. The Rakov Škocjan valley, with its natural bridges, is an excellent example.

In the case of Rakov Škocjan there is no necessity to invoke the involvement of significant tectonic structures. Relatively large cave chambers, later to be transformed into collapse dolines, develop mainly due to the direct influence of lithological contrasts. The underground stream retains its primary position because it can cope with removal of the total amount of collapsed material. 


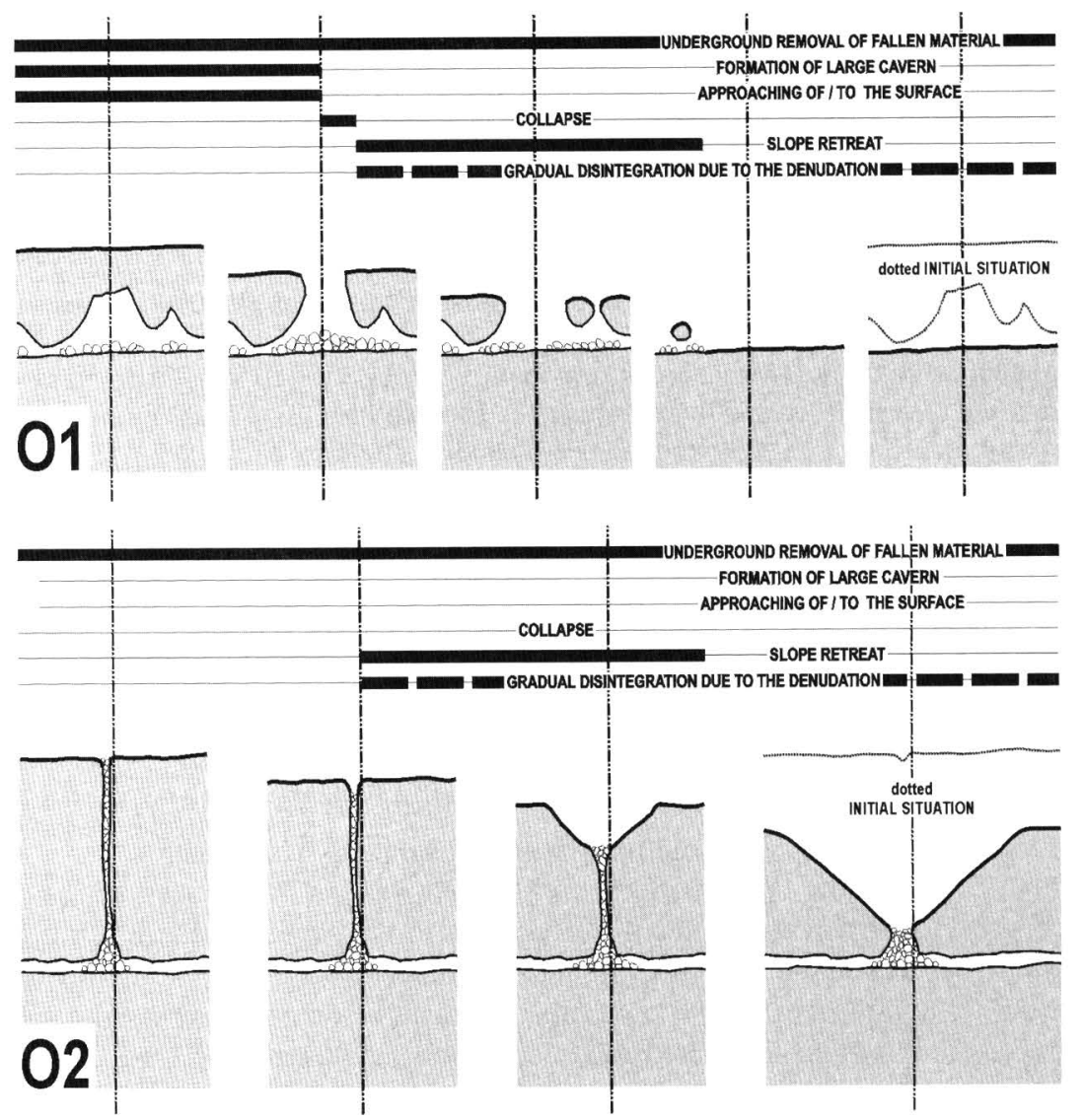

Fig.2 - Collapse dolines explained in terms of open system conditions. Note that the last stages (phantom dolines) are omitted from this figure (cases 01 and 02 ). The scale is different in each example, and in the $\mathrm{O} 2$ case the volume of the doline might be as much as 100 times larger than that in the previous case $(\mathrm{Ol})$.

Case O2: totally open system, deep underground stream (Fig.2, O2).

Present volumes of cave chambers such as Brezno pri Medvedovi konti (see Kortnik in this volume), which is $62 \times 10^{4} \mathrm{~m}^{3}$ (Šušteršič, 1973), appear to be "enormous". However, the doline that will evolve from such a chamber will not be spectacular, compared with the larger examples listed in Table 2. By reference to the example of the Rakovska kukava in the Classical Karst of south-central Slovenia, Šušteršič (1997) demonstrated that very large collapse dolines can evolve from relatively small cave chambers. However, a much more impressive example is provided by Laška kukava. This is nearly $100 \mathrm{~m}$ deep and its volume surpasses $4 \mathrm{Mm}^{3}$ (Table 2). There are two active foci of recent material removal in its floor (Sustersic, 1974).

Not far away a clue to the formational mechanism of this type of collapse doline 
is found in Riba jama. Here the whole of the accessible cave is a single, c.40m-deep cavern with an amoeba-like vertical section. Evidently this cavern formed by the simple settling down of tectonic crush within the shatter zone of a local strike-slip fault. The explanation is that underground water finds such zones difficult to break through. Consequently, once a route was opened, flow along it would persist, even if the passage was repeatedly obstructed by the ongoing periodic collapse of tectonic crush material. Such material being unstable, the process would continue until a Riba jama-like cave appeared at the surface. If the karst stream flow persisted long enough in the same position, the "cave" would eventually evolve into a doline, which would increase in volume until the stream flow ceased (start of closed system conditions), or until it appeared at the surface.

Evolution of Riba jama into a large collapse doline is, however, an extreme case. Provided that the underground stream is strong enough to cope with the debris production, achieving the necessary redistribution, all three cases presented as possible "closed system conditions" products can evolve further into an O2-type doline. Such cases may be even more common than the Riba jama case.

It must be stressed that the largest dolines of this type have volumes that surpass those of the largest cave chambers by a factor of about 20. Development of cave chambers of approximately similar volume is mechanically impossible (Šušteršič, 1973).

Table 2. Volumes of collapse dolines (popularly named kukave) and volumes of the largest known cave chambers in the area (partly revised, after Sušteršič, 1973).

\begin{tabular}{|l|c||l|l|}
\hline Collapse dolines & Big chambers \\
\hline \hline Laśka kukava & $4.17 \mathrm{Mm}^{3}$ & Gradiśnica / Blatna dvorana & $37.5 \times 10^{4} \mathrm{~m}^{3}$ \\
\hline Smrkovca & $1.60 \mathrm{Mm}^{3}$ & Najdena jama / Putickova dv. & $7.20 \times 10^{4} \mathrm{~m}^{3}$ \\
\hline Rakovska kukava & $1.35 \mathrm{Mm}^{3}$ & Najdena jama / Sulceva dv. & $5.00 \times 10^{4} \mathrm{~m}^{3}$ \\
\hline Dolga dolina & $1.10 \mathrm{Mm}^{3}$ & Logarcek / Blatna dvorana & $4.20 \times 10^{4} \mathrm{~m}^{3}$ \\
\hline Gladovec & $0.92 \mathrm{Mm}^{3}$ & Jama za Bukovim vrhom & $3.90 \times 10^{4} \mathrm{~m}^{3}$ \\
\hline Ivanjska kukava & $0.85 \mathrm{Mm}^{3}$ & Mačkovca/ Velika dvorana & $2.40 \times 10^{4} \mathrm{~m}^{3}$ \\
\hline Cerkniśka kukava & $0.53 \mathrm{Mm}^{3}$ & Logarcek / Podorma dvorana & $1.20 \times 10^{4} \mathrm{~m}^{3}$ \\
\hline
\end{tabular}

The "cases" examined above are not the only possibilities, and the options discussed here are those that appear to be supported by field observations. In other words, they are the options needed to explain, and allow understanding of, the collapse dolines of south-central Slovenia.

\section{Deflector faults, collector channels and collapse dolines}

Among the collapse dolines discussed above, those of $\mathrm{O} 2$ type are the least likely to be overlooked. Not only do they have the greatest volumes, they are also the most 
easily recognizeable, at least in the Dinaric Karst. Some of their characteristics need to be emphasized (Šušteršič, 1997, p237, Fig.2; Šušteršič et al., 2001):

- most of them lie on well-expressed tectonic lines, perpendicular to the general underground flow direction;

- only a few of them achieved the "last" stage, during which the stream appears on the surface;

- predominantly they are ranged in lines along a master fault, and the dolines in the line are of different ages (reflecting the stages of slope decay).

This implies that they are related to the underground hydrology, and also that their role must change over time. This aspect was studied in detail at several field locations by Šušteršič et al. (2001), and a summary of the main ideas is given below. The study set out to investigate the idea that large (several kilometres long) collector channels exist parallel to the margins of some karst poljes in Slovenia (Gams, 1965, p.87).

The main drain of the Cerkniško polje (Classical Karst, south-central Slovenia) is a system of four interconnected caves, known generally as Karlovice (Fig.3). The

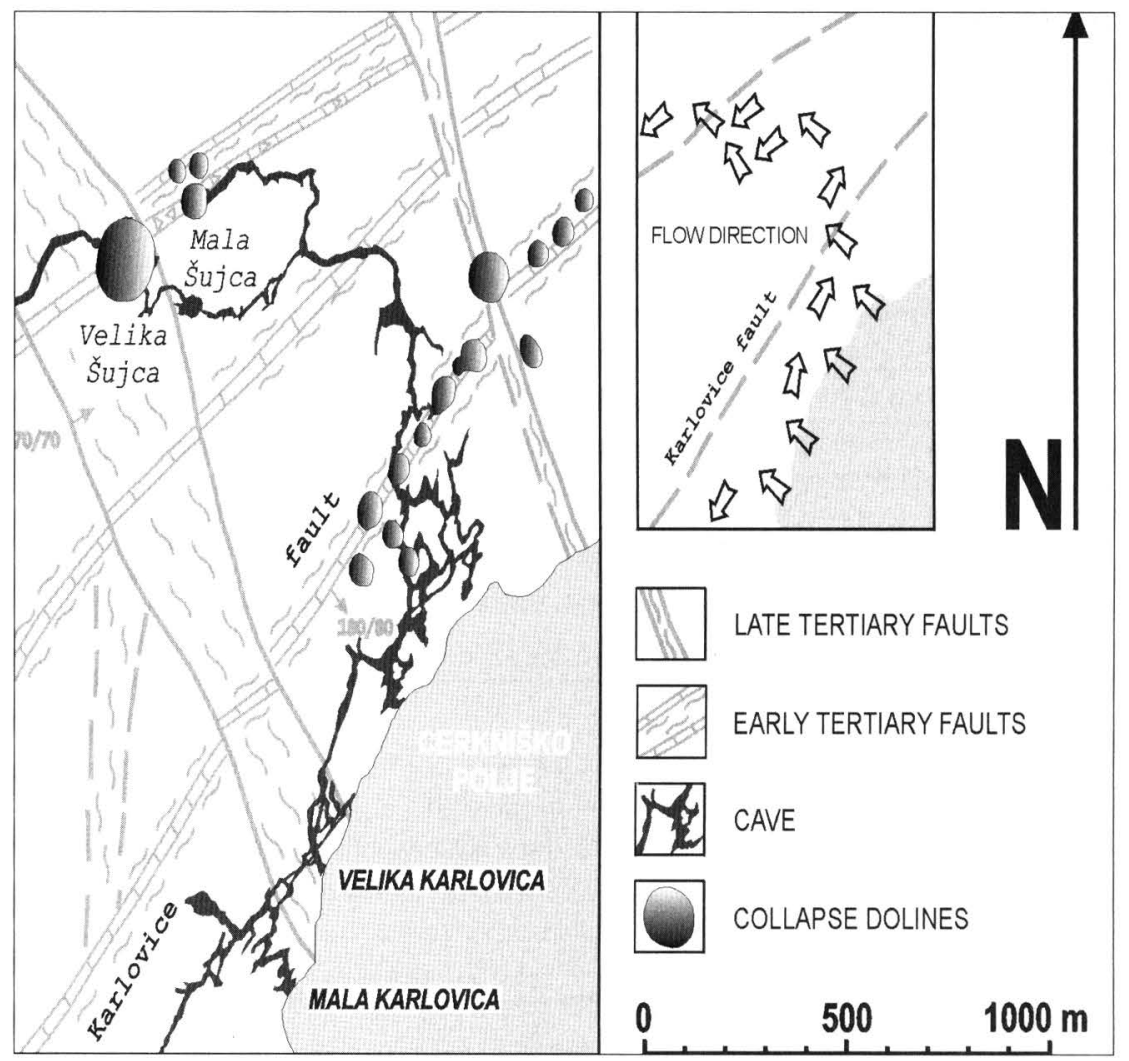

Fig. 3 - Tectonic, speleological and doline pattern at the northwestern border of the Cerkniško polje. 
total length of the presently known passages exceeds $8 \mathrm{~km}$. Due to the influence of deposits of Cerkniščica River dolomite gravel the general development of the cave was epiphreatic, but remnants of earlier phreatic shaping are still clearly recognizable.

Gams (1965) noticed that a string of channel segments, locally trending in various directions yet with a relatively consistent general alignment, extends parallel to, but about $100 \mathrm{~m}$ to $200 \mathrm{~m}$ away from, the polje margin. In view of their present function - collecting water from numerous streamlets sinking into small openings along the polje margin - Gams (o.c.) considered these segments to be parts of a collector channel. Gams stressed the parallelism of the collector channel with the polje margin. Its total length is nearly $2 \mathrm{~km}$ and its SW-NE orientation is approximately perpendicular to the dominant regional (Dinaric) tectonic trend.

In the wider area around Karlovice the polje border is more or less vertical (with walls up to $40 \mathrm{~m}$ high) and surprisingly straight for several kilometres. According to Car \& Gospodaric (1984) the polje border is tectonically guided. Thus, it might be expected that the parallelism of the collector channel is also somehow related to this guidance. However, the collector channel cannot run parallel to the polje border indefinitely. At some point the stream, endeavouring to flow away from the polje, must veer onto a direction perpendicular to the guiding structure. In other words, the fundamental condition for the formation of O2-type dolines must be fulfilled.

Within the cave Gospodarič (1970) identified several smaller faults on the same (perpendicular to Dinaric) trend, but limited access meant that no general conclusions could be drawn. Čar and Gospodarič (1984) recognized a regional fault on the same trend running a few hundred metres northwest of and parallel to the collector channel. This speleogenetically important fault was named Karlovški prelom (=Karlovice Fault) by Šǔsteršič et al. (2001).

The influence of the Karlovški prelom upon the cave system is obvious. On its southeast side (related to the part shown on Fig.3), the general trend of the collector channel is nearly straight. Active inlets deriving from the polje join it from the polje direction, whereas passages running away from the collector channel and away from the polje, towards the Karlovice Fault, are inactive and, as a rule, terminated by collapses.

Farther northeast the collector channel degenerates into a 3-D maze of scarcely accessible passages. Here also passages leading from the collector channel towards the Karlovice Fault are inactive, and choked by collapse. The main stream changes direction, becoming perpendicular to the Karlovice Fault trend. Gospodarič (1970) observed the fault zone at several points. Where the main stream crosses the fault zone ceiling collapse has modified the passage extensively. Surface mapping by Habič (1966) revealed several collapse dolines in different stages of decay at locations where currently unknown or inaccesible passages cross(ed) the fault.

Comparable relationships are repeated about a kilometre to the northwest, where the stream encounters a similar fault. It is evident that Karlovški prelom and the parallel fracture initially permitted water transmission perpendicular to their strike. However, as the passages continued to enlarge, the broken rock was too weak to maintain a stable arch. Subsequent roof collapse brought about formation of collapse dolines, whose floors continued to be undercut by the river until it had formed by- 
pass channels nearby. It must be remembered that broken zones, though initially more transmissive than the solid rock, are much less able to support channel formation. When the water has enlarged the pores/voids between the rock fragments sufficiently, the whole mass will settle down and the situation will return to the beginning. On the other hand, the bedrock channel will grow continuously and finally attract most of the flow. The same relationship also holds good between completely loose collapse boulders and the partly re-cemented broken zones of inactive faults.

Collapse of the cave roof at the points where the stream crossed the fault gradually forced the stream to concentrate into one collector channel, which runs parallel to the fault until reaching the point where water can (presently) cross it. Due to their "organizing" role such faults are termed deflector faults (Šušteršič et al., 2001, p.22), and all those so far studied are of early Tertiary age.

The collapse doline pattern evident on Fig. 3 indicates that the fault broken zone's transverse transmissibility must be relatively uniform, whereas its mechanical strength, permitting the formation and survival of larger passages, is low. The collapse dolines have reached various stages of decay, indicating that they must have formed at different times. However, their dimensions are modest and local conditions could have influenced their appearance (apparent "age") significantly. Also, their dimensions are still within the range of the largest cave chamber volumes, so that it is uncertain (though very likely) whether the subsequent enlargement characteristic of $\mathrm{O} 2$ type dolines took place.

This situation becomes obvious in the case of the Logarček cave (Fig.4), close to the northeastern border of Planinsko polje. Collapse dolines, some with volumes approaching $1 \mathrm{Mm}^{3}$, are clearly arranged along the early Tertiary Slavendolski prelom (= Slavendol Fault). The cave's main passage appears to "bounce" along it towards the north. In this case the deflector fault is not aligned parallel to the polje border, yet its influence upon the formation of collapse dolines and the collector channel is obvious. Other faults on a similar trend that formed later in the Tertiary are not implicated in collapse doline formation, though they have guided development of some chambers in the cave.

It is evident that the Slavendolski prelom fracture zone and related collapse dolines deflected the underground stream northwards. However, farther north in this string there is one more collapse doline. It lies about half a kilometre beyond the northernmost doline marked on Figure 4. Its volume is "only" $0.62 \mathrm{Mm}^{3}$ (Šušteršič, 1974, p.36) and it appears to be quite "fresh". Perhaps this is the location of the cave stream's present breakthrough of the Slavendolski prelom broken zone (Šušteršič et al., 2001).

\section{Conclusions}

Even allowing for the restricting condition that, by definition, at least a small component of cave roof free fall (collapse) is crucial, several genetic sub-types of collapse doline can be recognized and defined. 


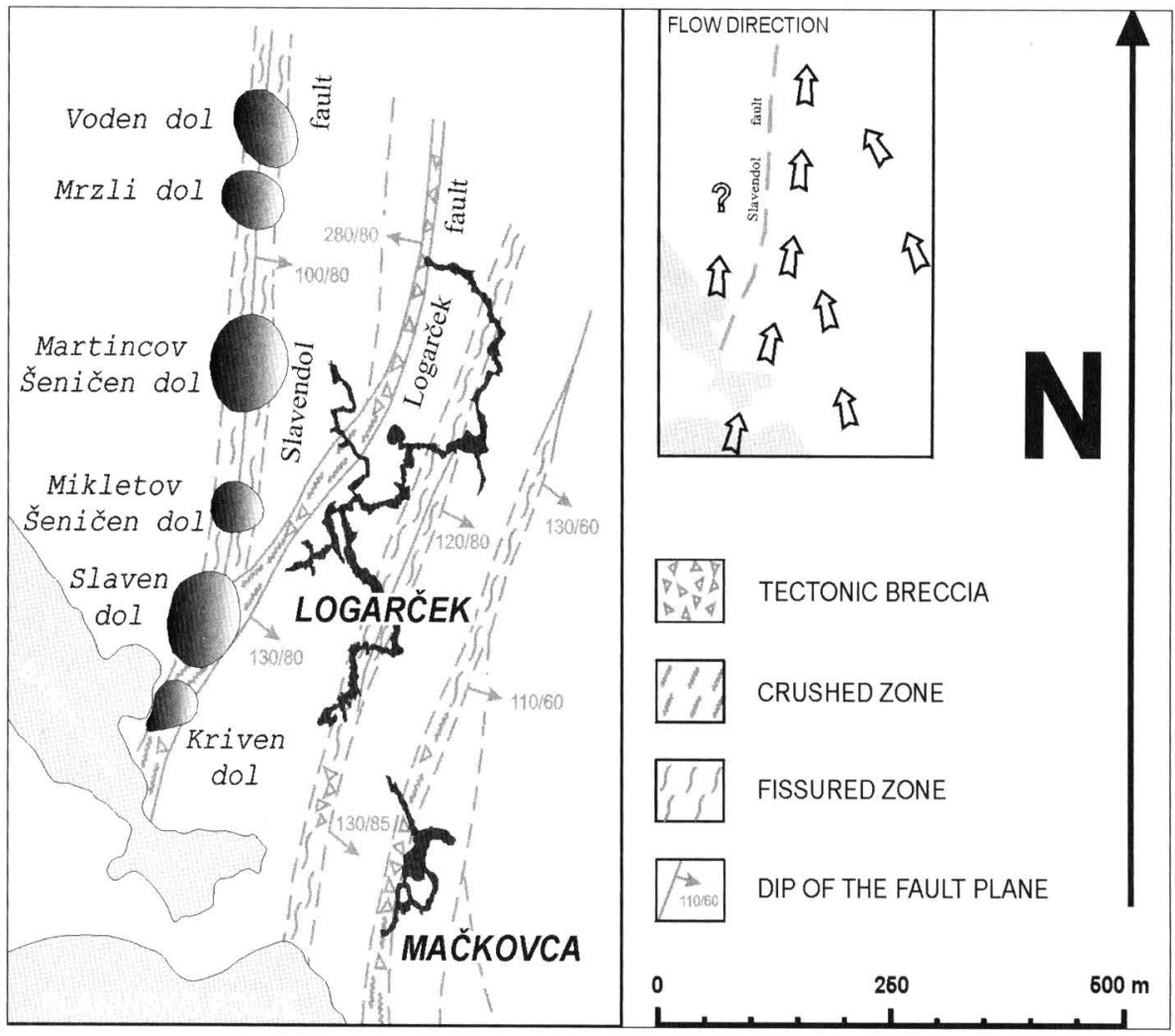

Fig.4 - Tectonic speleological and doline pattern at the northeastern border of the Planinsko polje.

The largest collapse dolines are those of type O2. These collapse dolines develop where cave streams cross a certain type of fault. Generally, several such dolines are aligned along a single master structure. The individual dolines are always of different ages (as best reflected by their degree of slope decay). Strings of type $\mathrm{O} 2$ collapse dolines do not reflect earlier cave directions; instead they indicate the locations of the main stream's breakthrough of a structural barrier.

Collapse doline formation (and the effects of collapse in general) where the underground stream breaks through the master fault gradually deflect the stream onto a direction parallel to the master fault. Faults that have this effect are termed deflector faults.

Long-term cave system development under the guidance of deflector faults brings about the formation of collector channels. Development of a collector channel is a direct consequence of flow corridor rearrangement in response to the existence of a less transmissive and less stable geological structure, lying athwart the regional hydraulic gradient. 
In combination with knowledge of the general hydrogeological conditions the mere existence of strings of type $\mathrm{O} 2$ collapse dolines on the surface offers information about the (likely) underground cave system organization.

\section{Acknowledgement}

Thanks to Dr.David J. Lowe for smoothing the English text, and for making many little suggestions that improved the contents.

\section{REFERENCES}

BRENČIČ M. 1992. Košelevc (Summary). Naše jame 34: 41-51.

CRAMER H. 1944. Die Systematik der Karstdolinen. Neues Jahrbuch für Mineralogie Geologie und Paläontologie Beilage Band Abt. B 85: 293-382.

ČAR J. 1982. Geologic setting of the Planinsko polje ponor area (Summary). Acta carsologica 10 (1981): 75-105.

ČAR J. AND GOSPODARIČ R. 1984. About geology of karst among Postojna Planina and Cerknica (Summary). Acta carsologica 12 (1983): 91-106.

FORD D. C. and WILLIAMS P.W. 1989. Karst geomorphology and hydrology. Unwin Hyman, London.

GAMS I. 1965. On the Quaternary geomorphogenesis of the area among the karst poljes of Postojna Planina and Cerknica (Summary). Geografski vestnik 37: 62-101.

GOSPODARIČ R. 1970. Spelological investigations of the Cerknica Cave System (Summary). Acta carsologica 5: 109-169.

GOSPODARIČ R. and HABIČ P. 1979. Karst phenomena of Cerknisko polje (Summary) Acta carsologica 8: 7-162.

HABIČ P. 1963. "Dolines" en forme de puits dites "koliševke" et le cours d'eau soutterain (Rèsumè). Treči jugoslavenski spelološki kongres, Speleološki savez Jugoslavije, Sarajevo: 1-272.

HABIČ P. 1967. Nova odkritja $v$ Veliki Karlovici [New discoveries in Velika Karlovica]. Naše jame 9: 52 - 54.

HABIČ P. 1978. Distribution of karst depressions in NW part of Dinaric karst (Summary). Geografski vestnik 50: 17-31.

JENKO F. 1959. The hydrogeology and water economy of karst (Summary). Državna založba Slovenije, Ljubljana.

LOWE D.J. and GUNN J. 1997. Carbonate speleogenesis: An inception horizon hypothesis. Acta Carsologica 26 (2): 457-491.

MARUSSIG M. AND VELKOVRH F. 1959. Gradišnica (Zusammenfassung). Naše jame 1 (1): $24-28$.

PRISTAVEC J. 2001. Raziskave v Katjini jami [Explorations in Katjina jama]. Nase jame 43: 90-95.

RENAULT P.H. 1967. Contribution á l'étude des actions mécaniques dans la spéléogenèse. Annales de spéléologie 22 (1): 5-596.

SCHEIDEGGER A.E. 1961. Theoretical geomorphology. Springer, Berlin. 
ŠUŠTERŠIČ F. 1973. On the problems of collapse dolinas and allied forms of high Notranjsko (Southcentral Slovenia) (Summary). Geografski vestnik 45: 71-86.

ŠUŠTERŠIČ F. 1974. Some metric problems on the collapse dolinas (Summary). Geografski vestnik 46:27-46.

ŠUŠTERŠIČ F. 1983. A simple model of the collapse dolines transformation (Summary). Acta carsologica $12: 1-32$.

ŠUŠTERŠIČ F. 1994. The Kloka cave and speleo-inception (Summary). Naše jame 36: 9 - 30.

ŠUŠTERŠIČ F. 1996. Poljes and caves of Notranjska. Acta carsologica 25: 251-289.

ŠUŠTERŠIČ F. 1997. Rakovska kukava - collapse or tumour doline? Acta carsologica 26 (2): 251-289.

ŠUŠTERŠIČ F. 1998. Interaction between the cave system and the lowering karst surface. Case study: Laški Ravnik. Acta carsologica 27 (2): 115-138.

ŠUŠTERŠIČ F. 1999. Vertical zonation of the speleogenetic space. Acta carsologica 28 (2): 187-201.

ŠUŠTERŠIČ F. 2000a. Are collapse dolines formed only by collapse? Acta carsologica 29 (2): 213-230.

ŠUŠTERŠIČ F. 2000b. Speleogenesis in the Ljubljanica river drainage basin Slovenia: $397-$ 406. In Klimchouk A.B., Ford D.C., Palmer A.N. and Dreybrodt W. (Eds.) Speleogenesis: Evolution of karst aquifers. Huntsville: Natl. Speleol. Soc.

ŠUŠTERŠIČ F., ČAR J. AND ŠEBELA S. 2001. Collector channels and deflector faults (Summary). Naše jame 43: 8-22.

ŽALEC P., VRHOVEC T., MIHAILOVSKI M., ZWÖLF D. and DROLE F. 1997. Jamski sitem Zeľ̌ke jame-Karlovica [Cave system Zelške jame-Karlovica]. Naše jame 39: 87-94. 